\title{
Evaluasi Program Corporate Social Responsibility Pelatihan Ecobrick dalam Mengelola Sampah Plastik
}

\author{
Sutin Narto $^{1^{*}}$, Basuki Agus Suparno ${ }^{2}$ \\ ${ }^{1,2}$ Program Studi Magister Ilmu Komunikasi, Universitas Pembangunan Nasional "Veteran" Yogyakarta \\ J1. Babarsari 2, Tambakbayan, Yogyakarta, 55281, Indonesia \\ Email: sutinnarto@gmail.com"; basuki.agus@gmail.com² \\ ${ }^{*}$ Corresponding author
}

\begin{abstract}
Garbage has been a world problem for a long time. The attention of the global community is now focused on the amount of waste, especially plastic waste that is scattered all over the sea and pollutes the ecosystem. Indonesia is a country with the second-largest amount of plastic waste pollution to the sea in the world. PT. Coca Cola is the number 1 contributor to plastic bottle waste in Indonesia and the world. PT Coca Cola has carried out many CSR activities to manage plastic bottle waste with a vision of a world without waste 2030, the program is Ecobrick Training which is given to three target schools. After implementing the Ecobrick training program, the impact of environmental changes has not been seen. The purpose of this study was to evaluate the Planning, Implementation, and Evaluation of PT Coca Cola Bottling Indonesia Central Java's Ecobrick Training CSR Program in managing plastic waste. The method used in this research is a descriptive qualitative evaluation study. Data collection was carried out by interview, field observation, and documentation study. Data analysis techniques using data analysis techniques Miles and Huberman. The theories used are planning theory and behavior change theory. The results of this study indicate that CSR Ecobrick Training does not provide benefits for the future. The CSR program planning process does not follow the correct CSR program planning standards. The planning of CSR programs at Coca Cola has not followed the correct CSR standards, namely not doing research, not conducting evaluation, and reporting. This study found a more targeted ecobrick training programplanning model, namely research, planning, executing, measuring, or evaluation (measure, and reporting).
\end{abstract} Keywords: Behavior Change; CSR Program; CIPP Evaluation Model

\begin{abstract}
Abstrak
Sampah telah menjadi masalah dunia sejak dahulu, dan hingga saat ini perhatian masyarakat global tertuju pada banyaknya sampah, terutama sampah plastik yang tersebar di penjuru laut dan mencemari ekosistem. Indonesia merupakan negara dengan jumlah pencemaran sampah plastik ke laut terbesar kedua di dunia. PT. Coca Cola adalah penyumbang sampah botol plastik nomor 1 di Indonesia dan dunia. PT Coca Cola telah banyak melakukan kegiatan CSR untuk mengelola sampah botol plastik dengan visi world without waste 2030, yaitu program pelatihan Ecobrick yang diberikan ke tiga sekolah binaan. Adanya program pelatihan Ecobrick nyatanya belum memberikan dampak perubahan lingkungan. Penelitian ini bertujuan mengevaluasi perencanaan, pelaksanaan, dan evaluasi program CSR pelatihan Ecobrick PT Coca Cola Bottling Indonesia Central Java dalam mengelola sampah plastik. Metode yang digunakan dalam penelitian ini adalah deskriptif kualitatif dengan studi evaluasi. Pengumpulan data dilakukan dengan wawancara, observasi lapangan, dan studi dokumentasi. Teknik analisis data dengan menggunakan teknik analisis data Miles dan Huberman. Hasil penelitian ini menunjukkan bahwa CSR Pelatihan Ecobrick tidak memberi manfaat untuk masa depan. Proses perencanaan program CSR tidak mengikuti standar perencanaan pembuatan program CSR yang benar. Perencanaan Program CSR di Coca Cola belum mengikuti standar pembuatan CSR yang benar, yaitu tidak melakukan riset terlebih, tidak melakukan evaluasi dan pelaporan. Penelitian ini menemukan model perencanaan program Pelatihan Ecobrick yang lebih tepat sasaran, yaitu penelitian (research), perencanaan (plan), pelaksanaan (execute), pengukuran atau evaluasi (measure), dan pelaporan (report). Kata kunci: Perubahan Perilaku; Program CSR; Model Evaluasi CIPP
\end{abstract}

\section{Pendahuluan}

Indonesia memiliki populasi pesisir sebesar 187,2 juta yang setiap tahunnya menghasilkan 3,22 juta ton sampah plastik yang tak terkelola dengan baik. Masyarakat kemudian menyoroti masalah sampah plastik, dengan melakukan gerakan pantai tanpa plastik, kampanye tanpa plastik, bahkan kementerian-kementrian membuat Gerakan Satu Juta Tumbler Generasi Tanpa Plastik. Gerakan yang bertujuan 
menumbuhkan kesadaran masyarakat untuk membatasi penggunaan plastik (Bintarti, 2019).

Berbagai gerakan yang dilakukan oleh masyarakat, perusahaan, bahkan pemerintah untuk mengurangi sampah plastik, namun kenyataanya sampah plastik tetap berserakan dimana-mana. Sampah masih menjadi masalah dunia sejak dahulu. Berdasarkan penelitian yang dilakukan oleh Jenna R. Jambeck dari University of Georgia pada tahun 2010, ada 275 juta ton sampah plastik yang dihasilkan di seluruh dunia. Sekitar 4,8-12,7 juta ton diantaranya terbuang dan mencemari laut.

Sekitar 0,48-1,29 juta ton dari sampah plastik tersebut diduga mencemari lautan. Data itu juga mengatakan bahwa Indonesia merupakan negara dengan jumlah pencemaran sampah plastik ke laut terbesar kedua di dunia. China memimpin dengan tingkat pencemaran sampah plastik ke laut sekitar 1,23-3,53 juta ton/tahun. Negara Philipina nomor tiga dengan 0,75 juta ton/tahun, Negara Vietnam menempati urutan ke empat dengan 0,73 juta ton/tahun, Rangking lima di duduki oleh Negera Sri Langka dengan 0,64 juta ton/tahun, Negara Thailand menempati urutan ke enam dengan jumlah sampah 0,41 juta ton/tahun, kemudian nomor tujuh oleh Mesir 0,39 juta ton/tahun, nomor delapan adalah Malaysia 0,37 juta ton /tahun, nomor Sembilan adalah Nigeria dengan 0,34 juta ton/tahun dan nomor sepuluh di tempati oleh Balangdesh 0,31 juta ton/tahun (Adharsyah, 2019).

Pada penelitian sebelumnya oleh Kusumawati, Setyowati, dan Salena (2018) ndonesia menjadi negara pembuang sampah laut plastik kedua terbesar di dunia setelah China, sesuai studi tahun 2010 yang dilakukan pada 192 negara pesisir oleh Jambeck et al. (2015). Indonesia dengan populasi penduduk di pesisir 187.2 juta jiwa dan kebiasaan masyarakat membuang sampah plastik ke laut $0.52 \mathrm{~kg} /$ orang/hari menjadikan Indonesia penyumbang sampah laut plastik sebesar 3.32 juta metrik ton/tahun (Jambeck et al. 2015).
Sampah plastik sulit terurai dan membutuhkan waktu yang sangat lama untuk terurai, berikut data penguraian jenis sampah di Indonesia. Ironisnya di Indonesia, banyak perusahaan minuman yang menggunakan botol plastik. Pada kuartal I-2019, pertumbuhan industri pengolahan minuman mencapai $24,2 \%$ secara tahunan (YoY), berada di bawah industri pakaian jadi. Banyak dari hasil akhir produk minuman menggunakan plastik sebagai packaging. Pertumbuhan industri minuman yang sangat pesat tentu saja menghasilkan pertumbuhan jumlah sampah plastik yang semakin banyak. Terlebih saat ini kapasitas pengolahan limbah plastik masih minim.

Prasetyo dan Kurniawan (2017) (2017) dalam jurnalnya yang berjudul Metode Konversi Sampah Plastik berupa Botol Plastik Bekas melalui budidaya Toga Dengan Sistes Vertikultur yang ramah lingkungan, mengemukakan bahwa penggunaan plastik dan barang yang terbuat dari plastik telah meningkat dari hari ke hari. Meningkatkan penggunaan plastik adalah konsekuensi dari perkembangan tekhnologi, industri dan populasi. Plastik sampah tersebut, hanya mampu dikelola 20-30 persen saja oleh pemerintah, sisaya hanya dilakukan penimbunan di kawasan pembuangan sampah akhir. Dengan semakin meningkatnya sampah plastik ini, dapat menjadi masalah serius apabila tidak dicari penyelesaiannya. Penanganan sampah plastik yang populer selama ini adalah dengan 3R (Reuse, Reduce, Recycle).

Berdasar audit yang dilakukan oleh Campaigner Greenpeace Indonesia pada September 2018, bahwa Coca Cola Indonesia menjadi brand internasional penyumbang sampah plastik terbesar di dunia. Campaigner Greenpeace Indonesia Muharram, menjelaskan sampah plastik Coca Cola mencapai 9.216 ton. Tempat kedua ditempati oleh Pepsi Co dengan 5.720 ton. Ada 10 besar perusahaan dari 10 brand internasional, Coca Cola menjadi yang terbesar menyumbang sampah plastik. Penyumbang 
sampah plastik lainnya adalah Danone (1.843), Nestle (2.950), Mondelez (1.664), Unilever (1.230), P\&G (1.324), Mars (678) dan Perfetti (1.085) (Ane, Ed: Abduk Rozak, 2019).

Coca Cola Indonesia menyadari produksi sampah yang dihasilkan, sehingga ingin melakukan tindakan redemption sebagai bentuk tanggungjawab sosial terhadap lingkungan dengan melakukan program CSR (Corporat Social Responsibility). Kesadaran PT Coca Cola Indonesia tertuang dalam program World Without Waste 2030. Program World Without Waste 2030 merupakan inisiatif dan menjadi prioritas bagi Coca Cola di Indonesia. Untuk di ASEAN dan di seluruh dunia, Coca Cola percaya bahwa permasalahan limbah kemasan plastik dapat diselesaikan dengan baik (advertorial CNN Indonesia, 2019).

Program Corporate Social Responsibility di Coca Cola Bootling Indonesia Central Java adalah Pelatihan Ecobrick, di mana program ini didesain untuk menginspirasikan perubahan perilaku kepada generasi muda mengenai pengelolaan sampah kemasan botol plastik. Di harapkan dengan pelaksanaan Pelatihan Ecobrick, masyarakat dapat mengurangi sampah plastik.

Program CSR Pelatihan Ecobrick juga dilakukan oleh delapan cabang Coca Cola di Indonesia, namun penelitian ini memfokuskan penelitian terhadap Coca Cola Semarang Jawa Tengah, karena target sasaran program CSR pelatihan Ecobrick yang berada di Semarang Jawa Tengah adalah anak-anak Sekolah Dasar Negeri Binaan di area ring satu (zone one), sedangkan tujuh cabang Coca Cola yang lainya menargetkan pelatihan ini untuk siswa sekolah menegah atas sampai dengan mahasiswa. Tujuan dari program pelatihan Ecobrick Coca Cola Semarang adalah ingin mengajarkan tentang kesadaran akan budaya sehat dan peduli lingkungan sejak dini.

Sekolah dasar yang menjadi binaan Coca Cola Semarang tidak hanya diberikan pelatihan Ecobrick, tetapi terdapat program lainnya juga diberikan secara berkelanjutan seperti, memberikan beasiswa kepada siswa dan siswi yang kurang mampu tetapi berpersetasi, Coca Cola juga memberikan pelatihan sepak bola pada para siswa di sekolah tersebut, mulai dari pemberian seragam untuk team sepak bola, sepatu bola, bola beserta pelatih sepak bola, Coca Cola juga memberikan pelatihan penanaman pohon terhadap sekolah tersebut, mengajarkan para siswa untuk belajar cara membuat pupuk, membibit tanaman serta memelihara bibit pohon. Coca Cola juga memberikan bantuan wastafel dan uang dalam bentuk bahan bangunan untuk membuat tempat cuci tangan yang digunakan oleh para siswaa di sekolah tersebut, Coca Cola juga memberikan bantuan tempat sampah untuk masing masing sekolah binaan.

Program CSR pelatihan Ecobrick sudah dilakukan pada bulan September 2019 dengan mengedukasi siswa siswi di beberapa sekolah dasar binaan di tingkat zone one. Sekolah yang menjadi target sasaran program CSR Coca Cola adalah SD Samban 01, SD Samban 02, SD Harjosari 01. Program CSR Pelatihan Ecobrick dilaksanakan dalam satu hari pelaksanaan dengan jumlah peserta ada 45 anak dan enam pendamping guru dari ketiga sekolah.

Program CSR pelatihan Ecobrick sudah selesai dilaksanakan oleh PT Coca Cola, akan tetapi belum terlihat dampak dari perubahan lingkungan setelah melakukan program CSR Pelatihan Ecobrick. Jika dilihat dari target sasaranya, program pelatihan Ecobrick ini sebetulnya terlalu berat jika di lakukan oleh anak anak di tingkat sekolah dasar.

Hasil penelitian prasurvei ditemukan bahwa evaluasi dan monitoring program pelatihan Ecobrick masih belum dilakukan oleh pihak PT Coca Cola Bottling Indonesia Central Java. Komunikasi sosialisasi tentang pengelolaan sampah plastik ternyata belum banyak diterima oleh masyarakat, dan selama ini sosialisasi tentang pengelolaan sampah plastik hanya dilakukan di ring satu atau di sekitar pabrik PT Coca Cola saja belum tersampaikan kepada 
masyarakat luas. Dari permasalahan diatas dapat di simpulkan rumusan masalah: "Bagaimana Evaluasi Program CSR pelatihan Ecobrick PT Coca Cola Bottling Indonesia Central Java dalam mengelola sampah plastik?". Tujuan penelitian untuk mengevaluasi perencanaan, pelaksanaan, dan evaluasi program CSR pelatihan Ecobrick PT Coca Cola Bottling Indonesia Central Java dalam mengelola sampah plastik.

\section{Konsep Dasar Corporate Social Responsibility}

John Elkington pada tahun 1997 dalam (Wibisono, 2007) melalui bukunya "Cannibals with Fork, the Triple Bottom Line of Twentieth Century Business". Elkington mengembangkan konsep triple bottom line dalam istilah economic prosperity, environmental quality dan social justice. Elkington memberikan pandangan bahwa perusahaan yang ingin berkelanjutan, harus memperhatikan "3P". Selain mengejar profit, perusahaan juga mesti memperhatikan dan terlibat pada pemenuhan kesejahteraan masyarakat (people) dan turut berkontribusi aktif dalam menjaga kelestarian lingkungan (planet).

CSR dikenal stakeholder. Menurut Rhenald Kasali (1994) dalam bukunya Managemen Public Relation, stakeholder adalah setiap kelompok yang berada di dalam maupun di luar perusahaan yang mempunyai peran dalam menentukan keberhasilan suatu peruahaan. Hal ini terkait Sustainable Development. Pembangunan berkelanjutan menurut Emil Salim (1982) bertujuan untuk meningkatkan kesejahteraan masyarakat, untuk memenuhi kebutuhan dan aspirasi manusia. Menurut Kementerian Lingkungan Hidup (1990) pembangunan (yang pada dasarnya lebih berorientasi ekonomi) dapat diukur keberlanjutannya berdasarkan tiga kriteria yaitu: (1) Tidak ada pemborosan penggunaan sumber daya alam atau depletion of natural resources; (2) Tidak ada polusi dan dampak lingkungan lainnya; (3) Kegiatannya harus dapat meningkatkan useable resources ataupun replaceable resource.
Terdapat jenis-Jenis Corporate Social Responsibility (CSR). Menurut Carroll (1979) mengklasifikasikan tanggung jawab sosial perusahaan ke dalam empat kategori, yaitu economic responsibilities, legal responsibilities, ethical responsibilities, dan discretionary responsibilities.

\section{Teori Perencanaan}

Menurut Cangara (2013:45), perencanaan komunikasi adalah suatu usaha yang sistematis dan kontinu dalam mengorganisir aktivitas manusia terhadap upaya menggunakan sumber daya komunikasi secara efisien guna merealisasikankebijaksanaankomunikasi. Model Perencanaan Komunikasi Lima Langkah Model perencanaan komunikasi lima langkah, terdiri atas lima tahap, yakni: Penelitian, Perencanaan, Pengukuran, dan Pelaporan

\section{Teori Perubahan Perilaku}

Perilaku manusia menurut Notoatmojo (2007:118) adalah semua tindakan atau aktivitas dari manusia itu sendiri yang mempunyai bentangan yang sangat luas baik yang dapat diamati langsung maupun yang tidak dapat diamati. Menurut Soekidjo Notoatmojo (1997: 120-121) perilaku dapat dibedakan menjadi dua macam, yaitu: perilaku pasif dan perilaku aktif

\section{Model Evaluasi CIPP}

Evaluasi konteks (context) dimaksud untuk menilai kebutuhan, masalah, aset dan peluang guna membantu pembuat kebijakan menetapkan tujuan dan prioritas.

Evaluasi masukan (input) dilaksanakan untuk menilai alternatif pendekatan, rencana tindak, rencana staf dan pembiayaan bagi kelangsungan program dalam memenuhi kebutuhan kelompok sasaran serta mencapai tujuan yang ditetapkan.

Evaluasi proses (process) ditujukan untuk menilai implementasi dari rencana yang telah ditetapkan guna membantu para pelaksana dalam menjalankan kegiatan. 
Evaluasi hasil (product) dilakukan dengan tujuan untuk mengidentifikasi dan menilai hasil yang dicapai (Stufflebeam et. al., 2003). (Stufflebeam, H McKee and B McKee, 2003:118). Evaluasi model CIPP dapat diterapkan dalam berbagai bidang. Nana Sudjana dan Ibrahim (2004:246) menterjemahkan masingmasing sebagai berikut: 1) Context: situasi atau latar belakang yang mempengaruhi perencanaan program pembinaan; 2) Input: kualitas masukan yang dapat menunjang ketercapaian program pembinaan; 3) Process: pelaksanaan program dan penggunaan fasilitas sesuai dengan apayang telah direncanakan; 4) Product: hasil yang dicapai dalam penyelenggaraan program tersebut.

\section{Metode Penelitian}

Peneliti menggunakan metode deskriptif kualitatif. Menurut Moleong (2005:4), pendekatan deskriptif kualitatif yaitu pendekatan penelitian dimana data-data yang dikumpulkan berupa kata-kata, gambargambar dan bukan angka. Data-data tersebut dapat diperoleh dari hasil wawancara, catatan lapangan, foto, video tape, dokumentasi pribadi, catatan, atau memo dan dokumentasi lainnya.

Teknik pengumpulan data dalam penelitian ini menggunakan: (1) Wawancara (interview), menurut Moleong (2005:186) menyatakan wawancara adalah percakapan dengan maksut tertentu, percakapan itu dilakukan oleh dua pihak, yaitu pewawancara (interviewer) yang mengajukan pertanyaan dan terwawancara (interviewer) yang memberikan jawaban atas pertanyaan itu (Burhan Bungin, 2003:155). (2) Observasi Lapangan (pengamatan), menurut W. Gulo (2002:116) merupakan metode pengumpulan data dengan mencatat informasi sebagaimana yang mereka saksikan selama penelitian. Observasi dilakukan di PT Coca Cola Bootling Indonesia, di Lokasi 3 Sekolah SD Binaan. (3) Dokumentasi, yaitu merupakan pencarian data mengenai hal-hal atau variabel yang berupa catatan, transkip, buku, surat kabar, majalah internal Coca Cola, notulen rapat Public Affair Community Sustainability, foto pada saat pembuatan ecobrick, (Arikunto, 1998:236). Menurut Moleong (2005:217-218)

Teknik analisis data pada penelitian adalah proses penyederhanaan data ke dalam bentuk yang lebih mudah dibaca dan diimplementasikan. Pada penelitian ini analisis data dilakukan menggunakan model Miles dan Huberman yang terdiri dari empat hal utama yaitu (Miles dan Hubberman, 1992:15).

Proses data yang dilakukan dengan menggunakan beberapa tahap diantaranya; (1) pengumpulan data, yaitu data yang diperoleh dari hasil observasi, wawancara, dan dokumentasi dicatat dalam catatan lapangan yang terdiri dari dua aspek, yaitu deskripsi dan refleksi; (2) reduksi data, yaitu proses pemilihan, pemusatan, perhatian pada langkah-langkah penyederhanaan dan transformasi data kasar yang muncul dari catatan tertulis dilapangan (Burhan Bungin, 2003:70); (3) penyajian data, yaitu data dibatasi sebagaimana sekumpulan informan yang tersusun dan memberikan kemungkinan adanya penarikan kesimpulan dan pengambilan tindakan; (4) penarikan kesimpulan, merupakan langkah akhir dalam pembuatan suatu laporan. Penarikan kesimpulan adalah usaha untuk mencari atau memahami makna, keteraturan pola-pola penjelasan, alur sebab akibat atau proposisi.

\section{Hasil Penelitian Dan Pembahasan Program CSR Pelatihan Ecobrick}

Program Pelatihan Ecobrick ini di dilakukan oleh Coca Cola dengan tujuan mengajarkan budaya sehat dan peduli lingkungan. Program ini diberikan ke masyarakat lingkungan pabrik Coca Cola Bawen Semarang yaitu para siswa SD di lingkungan zone one perusahaan. Menurut Pelaksanaan (implementasi) dalam CSR dirumuskan oleh Hadi (2011) mengenai diagram tahapan pelaksanaan CSR, yaitu perencanaan, pelaksanaan, dan evaluasi. 


\section{Tahap Perencanaan}

Menurut Hadi (2011), Perencanaan di dalam CSR adalah merupakan bagian terpenting dalam pelaksanaan CSR, proses perencanaan akan menentukan sejauh mana ketepatan dan keefektifan suatu program yang dirancang untuk target sasaran.

Hasil dari masukan di jadikan program dan dikirim ke National Office Jakarta. Program yang di setujui adalah program Pelatihan Ecobrick di submit ke National Office Jakarta melalui email.

\section{Tahap Pelaksanaan}

Pelakasanaan hari $\mathrm{H}$, siswa siswi yang akan di berikan pelatihan Ecobrick itu didampingi guru pendamping dari sekolah masing-masing. Pelaksanaan pelatihan di laksanakan di Coca Cola forest di lingkungan pabrik. Siswa dikenalkan dengan Ecobrick, dan diberikan pemahaman tentang bahaya membuang sampah sembarangan, selanjutnya siswa diberikan materi untuk pembuatan Ecobrick.

Pada saat pelaksanaa siswa siswi mengikuti pelatihan mengalami kesulitan selama pembuatan Ecobrick yaitu pemadatan isi botol kurang padat karena tenaga anak kurang kuat, sehingga dibantu guru untuk membantu memadatkan.

\section{Tahap Evaluasi}

Menurut Hadi 2011, evaluasi yang di lakukan dalam pelaksanaan CSR ditujukan sebagai acuan dalam perbaikan pelaksanaan di masa depan, sekaligus untuk menentukan tingkat pencapaian kinerja aktivitas sosial yang telah dilakukan. Evaluasi dan pemantauan pelaksanaan juga ditujukan untuk mengetahui sejauh mana kesesuaian pencapaian tujuan program yang telah dilakukan.

Pada penelitian Septianingsih, 2018 evaluasi pelaksanaan CSR ditujukan sebagai upaya untuk acuan dalam perbaikan pelaksanaan di masa depan, sekaligus untuk menentukan tingkat pencapaian kinerja aktivitas sosial yang telah dilakukan.
Evaluasi yang dilakukan oleh pihak Coca Cola sebanyak 3 kali yaitu komunikasi melalui telepon, datang mengunjungi sekolahan dan menanyakan secara langsung dengan siswa dan guru.

Model CIPP (Stufflebeam, H McKee and B McKee, 2003)

\section{Context}

Plastik menajadi salah satu alasan Coca Cola dalam membuat program CSR, hal ini disampaikan oleh PACS Pak rama, Coca Cola sudah memulai program pengolahan sampah plastik di tahun 2008 yaitu Bali Eco week. pelatihan Ecobrick selain mengurangi sampah plastik, juga bertujuan mengajarkan budaya sehat dan peduli lingkungan sejak dini. Program ini tidak besar tapi jika di lakukan secara berkelanjutan maka akan berdampak besar untuk planet bumi.

\section{Input, Proses, Produk}

Pendekatan yang dilakukan oleh pihak Coca Cola dengan mendatangi masayarakat desa sekitar dan beraudiensi dengan kepala desa setempat. Coca Cola menyampaikan program selama satu tahun kedepan.

Pelaksanaan Pelatihan Ecobrik hanya satu hari, pelatihan ini diikuti oleh 3 sekolah dasar dari zone one Coca Cola, yaitu Sekolah Dasar Samban 01, Sekolah Dasar Samban 02 dan Sekolah Dasar Harjosari 01. Pelatihan ini diikuti oleh 15 siswa dan 2 pendamping dari masingmasing sekolah. Total keseluruhan adalah 45 siswa dan 6 guru pendamping, sementara dari Coca Cola ada 2 dan dari mentor ada 2 orang.

Hasil dari pelaksanaan pelatihan Ecobrick adalah anak anak belajar tentang pengelolaan sampah, dan belajar tentang budaya sehat dan peduli lingkungan. Seperti yang di sampaikan oleh, sebagian besar anak anak sadar dan mengerti akan budaya sehat dan peduli lingkungan sejak dini, dan dari beberapa anak juga sudah mulai mengumpulkan sampah plastik dan dibuat Ecobrick sebagai pot bunga atau tempat duduk di rumah. 


\section{Evaluasi Perencanaan Pelatihan Ecobrick}

Public Affair Communication and Sustainbility dalam merencanakan program pelatihan Ecobrick menyampaikan kepada peneliti bahwa Coca Cola sudah melakukan penggalian kebutuhan CSR yang cocok untuk masyarakat, tetapi dari hasil wawancara peneliti terhadap masyarakat zone one mengatakan bahwa tidak pernah adanya penggalian informasi tentang kebutuhan CSR yang cocok untuk masyarakat setempat.

Perbedaan statment itu juga di utarakan oleh pihak sekolah yang menerima program pelatihan Ecobrick yaitu SD Samban 01, SD Samban 02 dan SD Harjosari 01. Bahwa Coca Cola tidak pernah mengajak diskusi dan menggali kebutuhan sekolah. Pihak Coca Cola hanya menyampaiakan ketika memberikan pelatihan Ecobrick untuk ke tiga sekolah tersebut. Pihak sekolah hanya menerima dan siap melaksanakan program pelatihan tersebut dan mempersiapkan semua kebutuhan untuk melaksanakan program pelatihan Ecobrick. Peneliti melihat bahwa proses penggalian informasi di masyarakat sebetulnya tidak pernah dilakukan oleh pihak Coca Cola, padahal untuk sebuah CSR yang baik harus ada penggalian informasi atau riset terlebih dahulu mengenai kebutuhan masyarakat sehingga bisa bermanfaat dan memberikan dampak positif terhadap keberlangsungan perusahaan. Program CSR Coca Cola sudah dibuat dan tinggal diaplikasikan kepada masyarakat. Hanya pada saat sosialisasi di masyarakat terdapat pengembangan yaitu Coca Cola menyampaikan ke masyarakat jika mempunyai program pelatihan, dan pelatihan tersebut ditawarkan kepada masyarakat, pelatihan apa yang masayarakat inginkan.

Menurut Cangara 2013, bahwa dalam perencanaan program diperlukan tahapantahapan yang harus dilakukan oleh pihak perusahaan yaitu meliputi penelitian (research) terlebih dahulu, dilanjutkan dengan perencanaan (plan) dan di dalam perencanaan terdapat strategi yang harus dipenuhi yaitu pemilihan atau penentuan sumber (komunikator), pesan, media, sasaran (segmen), dan efek yang diharapkan. Setelah perencanaan dibuat maka dilanjutkan pelaksanaan (execute), lalu dilakukan pengukuran atau evaluasi (measure) dan terakhir membuat pelaporan (report).

Berdasarkan hasil penelitian, program Corporate Social Responsibility pelatihan Ecobrick yang dilakukan oleh Public Affair Communication and Sustainbility Coca Cola Bottling Indonesia Central Java tidak terlihat adanya tahapan penelitian (riset) terlebih dahulu, Coca Cola langsung menentukan perencanaannya yang isinya sebagai komunikatornya adalah pihak Coca Cola, pesan yang ingin di sampaikan adalah perubahan perilaku budaya sehat dan peduli lingkungan sejak dini, media yang dipakai adalah tatap muka, whatsApp, media online radarsolo.jawapos.com, ungaranNews. com dan suaramerdeka.com. Target sasaran adalah tiga sekolah dasar yaitu SD Samban 01, SD Samban 02, dan SD Harjosari 01, yang diberikan pelatihan adalah siswa kelas empat dan kelas lima dari masing-masing sekolah. Dampak yang diharapkan Coca Cola dengan pelatihan Ecobrick yaitu penggunaaan konsumsi plastik menjadi berkurang.

Setelah selesai melaksanakan pelatihan Ecobrick Public Affair Communication and Sustainbility hanya melakukan meeting dengan internal membahas kemarin pelatihan sudah di lakukan. Evaluasi hanya dilakukan sebatas lisan saja, dan tidak di lakukan peninjauan ke sekolah sekolah. Ternyata evaluasi tersebut tidak dilakukan oleh pihak Coca Cola Semarang, sehingga peneliti menganggap bahwa program pelatihan Ecobrick hanya merupakan program saja dan seharusnya dilaksankan sebagai kegiatan sosial Coca Cola. Evaluasi perencanaan yang terakhir adalah Public Affair Communication and Sustainbility Coca Cola Bottling Indonesia Central Java juga tidak membuat laporan Program Pelatihan Ecobrick baik secara tertulis atau email. 
Penelitian ini di perkuat oleh penelitian Hutagaol Anggeh Afelina (2019) yang mengatakan bahwa perencanaan itu harus melalui analisis khalayak atau research terlebih dahulu, dilanjutkan dengan strategi tentang pemilihan atau penentuan sumber (komunikator), pesan, media, sasaran (segmen), dan efek yang diharapkan. Penelitian Afelina mendukung penelitian ini, di mana sebuah perencanaan program harus melaluiproses risetterlebih dahulu.

Penelitian ini juga didukung oleh Penelitian Viani Karlina Okta, 2017, bahwa perencanaan program yang tidak menggunakan perencanaan yang baik maka hasilnya juga tidak berhasil dengan baik. Hal tersebut memperkuat hasil penelitian ini, bahwa perencanaan itu di perlukan adanya riset terlebih dahulu. Program CSR harus ada report atau laporan secara tertulis dan di jadikan dokumen penting sebagai hasil dari program tersebut dan sebagai acuan atau referensi ketika membuat program yang serupa.

\section{Evaluasi Pelaksanaan Pelatihan Ecobrick}

Pelaksanaan Pelatihan Ecobrick dilaksanakan di Coca Cola Forest yang berada di belakang Pabrik Coca Cola. Peserta yang hadir ada 45 Siswa, dan dalam pelaksanaan pelatihan Ecobrick tidak ada kontijensi plan dari perencanaan. Ada sedikit perubahan pada saat pelaksanaan pelatihan Ecobrick yaitu pada saat praktek pembuatan Ecobrick adanya keterlibatan guru pendamping dari masing-masing sekolah ikut membantu dalam pembuatan Ecobrick.

Menurut Hadi (2011) dalam proses pelaksanaan CSR terdapat dua strategi implementasi, jika dilihat dari sudut pandang keterlibatan perusahaan dalam pelaksanaan CSR yaitu Self Managing Strategy dan Outsourcing. Pelaksanaan pelatihan Ecobrick pihak Coca Cola mengajak pihak luar sebagai mentor atau pemateri pelatihan Ecobrick yaitu dari Komunitas TUK (Tanam Untuk Kehidupan) Yayasan Cinta Ramah Lingkungan dari Salatiga.
Tahap perencanaan merupakan bagian terpenting dalam pelaksanaan CSR, proses perencanaan akan menentukan sejauh mana ketepatan dan keefektifan suatu program yang dirancang untuk target sasaran.

Menurut Hadi (2011) dalam proses pelaksanaan CSR terdapat dua strategi implementasi, jika dilihat dari sudut pandang keterlibatan perusahaan dalam pelaksanaan CSR yaitu Self Managing Strategy dan Outsourcing.

Tahap evaluasi pelaksanaan CSR ditujukan sebagai upaya untuk acuan dalam perbaikan pelaksanaan di masa depan, sekaligus untuk menentukan tingkat pencapaian kinerja aktivitas sosial yang telah dilakukan. Prayogo (2011:220) mengungkapkan bentuk evaluasi dapat ditentukan berdasarkan pendekatan program CSR yang digunakan.

Pelatihan Ecobrick dibuka oleh pihak Coca Cola sebagai penyelenggara dan dilanjutkan dengan pelatihan langsung. Acara dibagi dua sesi, yang pertama sesi pelatihan dan yang kedua sesi praktek. Penyampaian materi pembuatan Ecobrick oleh Bapak Kris selama kurang lebih satu jam, dan dilanjutkan dengan praktek. Siswasiswi SD sudah membawa bahan tambahan seperti sampah plastik dan tongkat kayu untuk memadatkan plastik ke dalam botol. Untuk botol disediakan oleh Coca Cola, namun ada juga yang membawa botol kosong sendiri.

Dalam pelaksanaan praktek terdapat hal yang harus dikoreksi yaitu teryata untuk memadatkan sampah plastik ke dalam botol membutuh tenaga ekstra, sehingga yang terjadi di lapangan adalah guru pendamping dari masing-masing sekolah juga turut membantu dalam memadatkan sampah plastik ke dalam botol. Hal tersebut dikarenakan jika dalam pengisian plastik ke dalam botol tidak padat maka Ecobrick tersebut tidak kuat. Pelaksanaan program pelatihan Ecobrick sudah sesuai dengan sesuai dengan perencanaan di lihat dari target peserta, lama waktu pelaksanaan pelatihan. 


\section{Evaluasi Hasil Pelatihan Ecobrick}

Hasil dari Evaluasi dari perubahan perilaku dari siswa siswi ketiga Sekolah Dasar Harjosari 01, Sekolah Dasar Samban 01 dan Sekolah Dasar Samban 02 mereka termasuk perilaku aktiv dalam melakukan perubahan budaya sehat dan peduli terhadap lingkungan sejak dini. Perubahan perilaku menurut Roger dikutip Notoatmodjo (2014), menjelaskan bahwa sebelum orang menghadapi perilaku baru dalam diri orang tersebut terjadi proses yang berurutan, yaitu: (1) Awareness atau kesadaran mengetahui terlebih dahulu terhadap struktur atau obyek. Anak SD Samban 01, Samban 02 dan Harjosari 01 menyadari betul terhadap sampah dapat memberikan dampak lingungan yang tidak baik, sudah tahu bagaimana mengelola sampah plastik dengan Ecobrick, siswa menyadari dampak lingkungan jika sampah tidak dikelola maka sampah tersebut menjadi permasalahan seperti penyakit. (2) Interest (dimana orang tersebut adanya ketertarikan). Anak anak SD Samban 01, Samban 02 dan Harjosari 01 tertarik untuk membuat Ecobrick di rumah, bahkan sebagaian dari siswa sudah ada yang mengumpulkan sampah untuk dibuat Ecobrick sebagai pot bunga. (3) Evaluation (menimbang terhadap baik dan tidaknya stimulus tersebut). Siswa-siswi SD melihat bahwa pelatihan Ecobrick adalah pelatihan yang bermanfaat dalam mengelola sampah plastik sehingga tidak merusak lingkungan, dan bisa berfikir bahwa melakukan pekerjaan kecil dapat berdampak besar untuk lingkungan itu lebih baik. (4) Trial (dimana orang telah mencoba perilaku baru). Di SD Samban 01 siswa-siswi yang mengikuti pelatihan ada yang sudah mulai mengumpulkan sampah plastik setiap hari dirumahnya, hal ini menunjukan adanya perubahan sikap dan perilaku siswa terhadap pengelolaaan sampah plastik, meskipun di SD lainya belum melakukan hal yang sama. (5) Adoption (dimana subyek telah berperilaku baru sesuai dengan pengetahuan terhadap stimulus). Dari ketiga SD yaitu SD Samban 01, Samban 02 dan Harjosari 01 yang kebanyakan berperilaku baru setelah adanya pelatihan Ecobrick adalah SD Harjosari 01 dan SD Samban 02, untuk SD Samban 01 belum merubah perilaku untuk hidup sehat dan peduli lingkungan. Hal berbeda justru pada guru pendamping dari SD Samban 01 yang merubah perilaku dengan hidup sehat dan peduli lingkungan, setelah mengikuti pelatihan melanjutkan dengan mnegumpulkan sampah dan mencoba membuat Ecobrick dirumah dan diajarkan pada arisan ibu-ibu PKK. Kenyataan menunjukkan bahwa yang giat dalam pengembangan pembuatan Ecobrick adalah guru pendamping siswa karena guru pendamping siswa sebagai ibu PKK yang kemudian diminta oleh masyarakat untuk mengajarkan pelatihan tersebut di berbagai pertemuan.

Dari hasil penelitian yang dilakukan ternyata tidak banyak dari siswa dan siswi yang merubah perilaku budaya sehat dan peduli lingkungan. Jika ada yang berubah itu dikarenakan memang siswa siswi tersebut memang sudah diajarkan dari orang tuanya untuk hidup sehat dan peduli lingkungan sejak dulu atau memang budaya sehat dan peduli lingkungan sudah di tanamkan oleh sekolah sejak dini.

Hasil temun adalah adanya perubahan presepsi target segment yang sebetulnya yang tidak sesuai, yaitu target program pelatihan Ecobrick adalah siswa siswi pelajar tingkat SD, ternyata program pelatihan Ecobrick lebih cocok diberikan kepada ibu-ibu PKK.

Program CSR pelatihan Ecobrick yang di lakukan oleh Coca Cola terkesan hanya sekedar menggugurkan kewajiban, seolah-olah program CSR hanya program yang sudah dibuat dalam setiap tahunya dan hanya sekedar dilaksanakan

\section{Context}

Contex dalam hal ini adalah Coca Cola sebagai penghasil sampah nomor satu di dunia, Coca Cola ingin melakukan redemption atau penebusan dosa tanggungjawab terhadap lingkungan karena sudah melakukan pencemaran 
lingkungan, sehingga Coca Cola dalam revolusinya membuat visi Wolrd Without Waste 2030. Banyak kegiatan yang sudah dilakukan oleh coca Cola untuk mewujudkan visi tersebut diantaranya adalah program pelatihan Ecobrick, tetapi yang di lakukan oleh Coca Cola Semarang sangat unik karena target pesertanya siswa-siswi sekolah binaan Coca Cola. Peneliti melihat bahwa pelatihan Ecobrick terdapat kelemahan dan kekuatan dari program tersebut. Kelemahan program antara lain; (a) target sasaran program ini kurang tepat apabila diberikan kepada siswa siswi SD di lingkungan pabrik Coca Cola, di mana dalam proses pembuatanya juga dibutuhkan tenaga yang besar hingga Ecobrick dapat dijadikan produk yang bermanfaat. (b) waktu yang dibutuhkan untuk mengumpulkan sampah itu membutuhkan waktu yang lama.

Untuk kekuatan program diantaranya adalah satubotol 1 liter Ecobrickbisa diisi dengan sampah plastik sekitar 1,5 kilogram, sehingga plastik yang banyak dapat dengan ringkas dimasukan ke dalam satu botol plastik. (b) Hasil kerajinan dari Ecobrick berupa karya seperti tempat duduk, vas bunga, rak buku, sampah plastic yang bernilai ekonomi jika di kelola dengan baik.

\section{Input}

Peneliti melihat dalam perencanaan pihak Coca Cola tidak melakukan riset terlebih dahulu dan tidak meminta masukan dan saran dari sekolah dan warga sekitar sehingga pelatihan Ecobrick ini menjadi kurang tepat jika di tujukan kepada siswa siswi sekolah dasar, perencanaan yang tidak dilakukan riset terlebih dahulu hasil program yang dihasilkan tidak dapat maksimal dan berpotensi salah sasaran. Hasil dari pelatihan Ecobrick hanya sebatas program yang dijalankan sajadantidakmenimbulkanperubahanlingkungan atau perubahan perilaku terhadap target sasaran

\section{Process}

Pelaksanaan program pelatihan Ecobrick dilaksankan sesuai dengan awal perencanaan yaitu di lakukan di Coca Cola Forest, ada 45 siswa yang mengikuti pelatihan Ecobrick, jumlah siswa sudah sesuai dengan target awal rencana. Siswa masing-masing sekolah membawa peralatan tongkat kayu dan sampah plastik, sementara botol plastik disediakan oleh pihak Coca Cola. Coca Cola, juga menyiapkan konsumsi makan dan minum, mentor atau pemberi materi, hadiah berupa buku dan alat tulis serta produk Coca Cola. Untuk rundown pelaksanaanya sesuai dengan rencana awal, rencana awal di mulai pada pukul 08:00 dan selesai pada pukul 12:00 di akhiri dengan penyerahan hadiah.

Perubahan yang tidak signifikan terjadi pada saat praktek pembuatan Ecobrick, banyak siswa dibantu oleh guru pendamping dalam proses memadatkan sampah, karena untuk menjadi Ecobrick harus benar-benar padat, agar ketika digunakan sebagai karya yang lain hasilnya menjadi maksimal.

\section{Product}

Hasil yang dicapai dalam penyelenggaraan program pelatihan Ecobrick adalah siswa bisa membuat Ecobrick. Jika dikaitkan dengan tujuan programpelatihan Ecobrick hasilnyabelum sesuai dengan tujuan awal yaitu perubahan perilaku budaya hidup sehat dan peduli lingkungan sejak dini. Hasil temuan peneliti, bahwa tidak semua siswa yang mengikuti benar-benar merubah perilaku untuk peduli lingkungan, hanya beberapa siswa yang peduli dengan lingkungan yaitu mempraktekan pembuatan Ecobrick di rumah, mulai dari pengumpulan sampah plastik sampai membuat Ecobrick sendiri. Sebagian besar siswa hanya memahami cara pembuatan Ecobrick, dengan kata lain banyak siswa yang tidak mempraktekan pengumpulan sampah dan pemilahan sampah dirumah dan di buat Ecobrick.

Hasil lanjutan setelah siswa mengikuti pelatihan Ecobrick dan dari Coca Cola membuat kompetisi terhadap ke tiga sekolah untuk membuat hasil karya dari Ecobrick. Jika dikaitkan dari hasil akhir pelatihan Ecobrick, tujuan pelatihan Ecobrick menjadi lebih tepat yaitu mengajarkan siswa siswi untuk membuat karya yang benilai ekonomi, bukan untuk 
melakukan perubahan perilaku budaya sehat dan peduli lingkungan, tetapi jika mengajarkan siswa untuk membuat karya yang bernilai ekonomi sepertinya kurang tepat sasaran, karena belum saatnya siswa membuat karya yang brenilai ekonomi. Lebih tepat jika pelatihan ini diberikan kepada orang dewasa yang memahami tujuan pelatihan dan hasil karyanya mempunyai nilai ekonomi, dan dapat menjadi penghasilan.

Model perencanaan ini adalah melengkapi model perencanaan Cangara 2013. Sebaiknya dalam melaksanakan program benar-benar melakukan tahapan-tahapan baku dalam pembuatan program CSR. Di mulai dengan melakukan riset terlebih dahulu, sehingga program dapat sesuai dengan kebutuhan masyarakat ataupun perusahaan. Tahapan selanjutnya adalah planning yang di dalamnya ada strategi tentang pemilihan atau penentuan sumber (komunikator), pesan, media, sasaran (segmen), dan efek yang diharapkan. Di lanjutkan dengan tahapan evaluasi yang disesuaikan dengan tujuan awal program. Tahap terakhir adalah tahapan pelaporam atau report, dalam membuat program CSR harus membuat laporan tertulis dan dilaporkan kepada top management sebagai bentuk pertanggung jawaban sudah melaksanakan program dan pengeluaran budget untuk program tersebut.

\section{Simpulan}

Simpulan penelitian Evaluasi Program CSR Pelatihan Ecobrick PT Coca Cola Bottling Indonesia Central Java dalam mengelola sampah, pada tahap perencanaan terdapat perbedaan informasi terkait dengan proses pembuatan program CSR Pelatihan Ecobrick. Perbedaan statment diutarakan oleh pihak sekolah yang menerima program pelatihanEcobrickyaitu sd SD Samban 01, SD Samban 02 dan SD Harjosari 01.

Perencanaan program CSR Pelatihan Ecobrick tidak melalui tahapan Riset terlebih dahulu. Tahapannya meliputi penelitian (research), perencanaan (plan) (segmen), dan efek yang diharapkan. Setelah perencanaan dibuat maka dilanjutkan pelaksanaan (execute), laludilakukan engukuran/evaluasi (measure) dan terakhir membuat pelaporan (report).

Evaluasi tidak dilakukan oleh pihak Public Affair Communication and Sustainbility yang tidak membuat laporan Program Pelatihan Ecobrick baik secara tertulis yang seharusnya dilaporkan kepada Coca Cola Indonesia, National Office Jakarta. Pada pelaksanaan pelatihan Ecobrick terdapat sedikit perubahan yaitu pada saat praktek pembuatan Ecobrick ada keterlibatan dari para guru pendamping dari masing-masing sekolah yang ikut membantu dalam pembuatan Ecobrick.

Dan hasil evaluasi terhadap perubahan perilaku dari siswa siswi ketiga Sekolah Dasar Harjosari 01, Sekolah Dasar Samban 01 dan Sekolah Dasar Samban 02, ternyata tidak banyak dari siswa siswi yang merubah perilaku budaya sehatdanpedulilingkungan, karenatargetsegment yang sebetulnya tidak sesuai untuk siswa SD, dan lebih tepatt diberikan kepada Ibu-ibu PKK.

Rekomendasi penelitian ini untuk pihak PT Coca Cola Bottling Indonesia Central Java. Dalam tahapan perencanaan program harus melakukan riset atau penelitian terlebih dahulu, sehingga program sesuai dan mempunyi dampak di masyarakat. Tahapan planning harus dibuat dengan tepat agar tujuan perusahaan dapat tercapai. Tahapan evaluasi secara berkala harus dilaksanakan sebagai bentuk tanggungjawab dari penyelesaian program. Tahapan report harus dibuat dan dipertanggungjawabkan ke pimpinan baik tertulis atau lisan. Saran bagi pihak SD Samban 01, SD Samban 02 dan SD Harjosari 01, diharapankan dapatselalu aktif dalam melaporkan perubahan dampak setelah siswa siswi mengikuti dan melaksanakan program pelatihan Ecobrick dan mengajak Coca Cola untuk bekerjasama terkait dengan pelatihan lain, bukan sekedar menerima program yang tidak ada kelanjutanya.

Penelitian ini menemukan model perencanaan program Pelatihan Ecobrick yang lebih tepat sasaran, yaitu penelitian (research), perencanaan (plan), pelaksanaan (execute), pengukuran atau evaluasi (measure), dan pelaporan (report). 


\section{Daftar Pustaka}

Adharsyah, T. (2019). Sebegini Parah Masalah Plastik di Indoensia. Retrived Descember 10, 2019, from: https://www.cnbcindonesia. com/lifestyle/20190721140139-33-86420/ sebegini-parah-ternyata-masalahs a m pah-plastik-di-indonesia Ane, Ed: Abdul Rozak. (2019). Coca Cola Penyumbang Sampah Plastik Terbesar di Dunia. Retrived December, 2019. From: https:// www.gatra.com/detail/news/419108/ gaya $\% 20 \mathrm{hidup} /$ coca-cola-penyumbangs a m pah-plastik-terbesar-di-dunia ArchieB.Carroll.(1979).AThree-Dimensional Conceptual Model of Corporate Social Performance, Academy of Management Review. Arikunto, Suharsimi. (2007). Evaluasi Program Pendidikan. Jakarta: Bumi Aksara. Bintarti, Ana. (2019). Mengelola Sampah Memang Tidak Mudah: Proyeksi 2020 Bidang Lingkungan. Retrived December 27, 2019, from: https:// www.nusabali.com/berita/65899/ mengelola-sampah-memang-tidak-mudah

Bungin, B. (2003). Analisa Data Penelitian Kualitatif: Pemahaman Filosofis dan Metodologis ke Arah Penguasaan Model Aplikasi. Jakarta: Raja Grafindo Persada. Cangara, H. (2014). Perencanaan dan Strategi Komunikasi. Jakarta: PT Rajagrafindo Persada. Emil Salim. (1989). Lingkungan Hidup dan Pembangunan, Mutiara Sumber Widya, Jakarta. Gulo, W. (2002). Metodelogi Penelitian. Jakarta: Gramedia Widia Sarana Indonesia Hadi, Nor. (2011). Corporate Social Responsibility. Yogyakarta: Graha Ilmu Hutagaol Anggeh Afelina. (2019). Perencanaan Komunikasi Indonesian Youth Educate And Social Dalam Mengimplementasikan Program I-YES Mengajar. JOM FISIP, 6(1), 1-12 Jenna, R. Jambeck. (2015). Plastic Waste Inputs from Land into the Ocean. University of Georgia
Kasali, Rhenald. 1994. Manajemen Public Relations: Konsep Dan Aplikasinya Di Indonesia. Jakarta: Pustaka Utama Grafiti. Kusumawati, I., Setyowati, M., \& Salena, I. Y. (2018). Identifikasi Komposisi Sampah Laut Di Pesisir Aceh Barat. Jurnal Perikanan Tropis, 5(1), 59-69 Moleong, J.Lexy. (2000). Metode Penelitian Kualitatif. Bandung: Rosda Karya. Miles, B. Mathew dan Michael Huberman. (1992). Analisis Data Kualitatif Buku Sumber Tentang Metode-metode Baru. Universitas Indonesia, Jakarta Nana Sudjana, \& Ibrahim. (2004). Penelitian dan Penilaian Pendidikan. Bandung: Sinar Baru Algesindo Notoatmodjo, S. (2007). Promosi Kesehatan dan Ilmu Perilaku. Jakarta: Rineka Cipta. Prasetyo, Y., \& Kurniawan, A. (2017). Metode Konversi Sampah Plastik Berupa Botol Plastik Bekas Melalui Budidaya Toga Dengan Sistem Vertikultur Yang Ramah Lingkungan. Gontor Agrotech Science Journal, 3(2), 85-98. Prayogo, D. (2011). Socially Responsible Corporation: Peta Masalah, Tanggung Jawab Sosial dan Pembangunan Komunitas pada Industri Tambang dan Migas, UI Press., Jakarta. Septianingsih M, Mega. (2018). Evaluasi Program Corporate Social Responsibility (CSR) PT PERTAMINA (PERSERO) Refinery Unit IV Cilacap, Universities $\mathrm{M} \mathrm{uh}$ a m m ad i y a h Y g y a k a r t a . Stufflebeam, D.L. H McKee and B McKee. (2003). The CIPP Model for Evaluation. Paper presented at the 2003 Annual Conference of the Oregon Program Evaluation Network (OPEN). Portland: Oregon. Viani Karlina Okta, (2017), Pentingnya Perencanaan dalam Program Imunisasi di Dinas Kesehatan Kota Surabaya. Jurnal Ahli Kesehatan Indonesia, 5(2) 105-110 